\title{
Masterless Men in a Masterful Land: Judith Wright's Generation of Men
}

\author{
Devaleena Das \\ Gurudas Mahavidyalay, India
}

\begin{abstract}
Judith Wright in Generation of Men reconstructs her past generations and their resilient struggle to master the alien landscape with all its traumas, pain and struggle in order to transform it to a 'place'. This paper tries to locate Wright's passionate attempt in this book to see the unique landscape of Australia as linked inextricably to the erosion, endurance and struggles of the mindscape of humanity, and to see how the landscape inheres the alterities of the spatial/cultural binarism. In this landscape a Protean mystery dies with the death of the black aboriginals but is once more reborn in the poet's mnemonic homage. The paper tries to establish Wright as being above the category of a mere environmentalist, and argues for her poetics as a humanist celebration of Australia as a landscape of cornucopia as well as a problematization of the spatial dimensions of oppression and denial unacknowledged in a history of national reconciliation.
\end{abstract}

Key Words: Judith Wright, Australia, poetry, aboriginal, landscape, history, space/ place.

"The landscape I knew was full of a deep and urgent meaning...these hills and plains...these rivers and plants and animals were what I had to work with as a writer, and they themselves contained the hidden depths of a past beyond anything that cites and the British invasion had to offer."

Judith Wright, Going on Talking

Landscape with its natural environment in Australian literature is a predominant theme from the time of colonial settlement and is a discourse of representation of determined spaces historically, geographically and culturally. Writing about the 'spatial history' of Australia in his Road to Botany Bay: An Essay in Spatial History, Paul Carter argues that poetry, no less than painting and town-planning, has been implicated in the process of colonization through which the existing environment is erased and remade to suit the newcomers' predilections (Carter xxff). In enumerating on landscape and its perspective Carter shows how the "settlers build in order to stabilize the ground, to provide ourselves with a secure place where we can stand and watch" (Carter 165). Judith Wright, one of Australia's greatest writers and environmentalists had repeatedly dealt with the nation's landscape ranging from the psychosis of fear of the settler to the beauty and mystery of the land. In her elegant chronicle The Generation of Men she reconstructs her past generations and their resilient struggle to master the alien landscape with all its traumas, pain and struggle in order to transform it to a 'place'.

Rupkatha Journal on Interdisciplinary Studies in Humanities (ISSN 0975-2935), Vol 2, No 2, 2010

URL of the Issue: http://rupkatha.com/v2n2.php

URL of the article: http://rupkatha.com/V2/n2/JudithWrightGenerationofMen.pdf

(C) www.rupkatha.com 
Transgressing the boundary of a white woman writer, in the book The Generation of Men Wright traces the forceful possession of the 'worthless land' by her past generations with its attendant repressed sense of guilt, the 'masterless men', along with the simultaneous attempt to dispossess the natives turning them 'homeless' and thus making them 'out of place':

"My grandfather's diaries from which I wrote the story, seldom mentioned the people of the country on which he had intruded, except as they affected his work as a pastoral 'pioneer'..." (Wright Foreword)

For these 'generations of men' Australia is a 'wild undisciplined colony', 'a worthless land', the terra nullius where the 'treacherous tribes' are nonexistent, it's a landscape waiting to be mapped and named, a landscape of material topography watched through the lens of being an outsider until they invest their own meaning, inhabiting and transforming it into a 'place'.

To be homeless does not simply mean to be without a home. Homelessness is very much defined by a certain kind of disconnection from particular forms of place which in this case refers to the English landscape of daffodils and nightingales unlike the 'wild undisciplined colony' of damnation, sin, vast arid sweeps of deserts, 'rivers of stupidity', 'treacherous tribes', awkward kangaroos, emus, hidden bunyips in the mud, or 'gigantic lilies'. Wright depicts this strangeness in her great grandmother Margaret Wyndham first time after her arrival:

"It had been strange indeed to Margaret, used to the cared-for- fields and woods of France and England, to look out into that green alarming depth... The orchids and parasite plants that flowered on the tall trees were all strangers; the blacks, the animals, and particularly the insects frightened her-the big greened mantistes, their heads turning eerily to watch her movements, the many legged creatures.... the moths that blundered into the weak flames of the tallow-dip candles at night left her in dark." (Wright, 4, 5)

Home is therefore a unit of space organized mentally and materially to satisfy people's basic biosocial needs and their aesthetic-political aspirations. Wright's first generation, the 'masterless men' attempted desperately to master the landscape taming it into a land of comfort. The 'masterless men'a term developing during the Elizabethan times, refers to English vagrancy when a large number of people, formally attached to the land of their masters, were freed from feudal ties and started to wonder the land. The free roaming vagabonds searched for new land transforming it from feudalism to early capitalism and thus driving away the aborigines-an essential part of Australian landscape as radically 'out of place' not matching the expected relations between landscape, place and practices. In return the aborigines thus become homeless. The settlers attempted to see this new landscape 
with a Eurocentric perspective as rationally ordered, harmoniously designed, waiting to be mapped and named.

W. J. T Mitchell in his essay Imperial Landscape argues that landscape traditions developed during British Imperial power and its representation is a western practice. In The Generation of Men Wright shows how initially the landscape appeared to be hostile, unbearable, "The bare country they were crossing gave no shelter; he began to feel this wind as a personal enemy, intent on snatching away the very clothes he huddled in." (Wright 194) It appears as a dark savage land as Wright delineates "it seemed now that the country was deliberately playing with him," and for Albert, her grandfather "the place was poisoned for him" as a 'fever country' of malnutrition, illness, and death (Wright 156).

But this landscape is the dream work of imperialism, the subject of utopian fantasies meant for cartography, architecture, land surveying, mapping rationally and territorializing. In spite of the first generation's attempt to master the land, it remained untamable, "in the fight to master the land, it had in fact begun to master him" (Wright 114). Wright beautifully shows this revolutionary spirit in the mysterious land itself whose rich dark soil, poisonous plants, mosquitoes, ague, the dreadful fever and innumerable deep ravines and gorges failed to accommodate the crops the settlers wanted to grow. In their desperate attempt to "fence jealously marking the limits of their encroachment" (Wright 135), to build up roads, farmhouses, townships, what is left at the end is exasperations. "Wires were often broken", posts uprooted by emus and kangaroos, "the dingoes,... were as yet puzzled and mistrustful", and the natives "broke fences, spoiled musters and occasionally came down into Albert's cleared country and made inroads, as the kangaroos did, on the sweet rich pastures over which Albert felt so possessive" (Wright 107, 108, 134). While describing the 'Northern venture' Wright describes "Kangaroos and wallabies grazed everywhere...Albert flicked his whip irritably at the kangaroos; they were eating the grass and drinking the water that he felt belonged by right to his sheep and cattle" (Wright 117). When the second generation finally tamed "the wild country that had defeated their forerunners", Albert, "whose life had been spent among the crude and makeshift devices of the bush, could feel the upwelling of change..." (Wright 99).

This change is not merely in the topography of the landscape but more important is in the mindscape of the 'Third Generation'. While writing about May, Wright's grandmother, she attempts to delineate her love for the land inspite of her great grandfather's desperate attempt to cling to the clichés of English landscape. Instead May is fascinated by the native flowers, 'snakes of extra ordinary colours', lizards and the evergreen bush. "On her account, the landscape was coming alive in his mind." "May gazed out with the elation of adventure at the landscape...Mills and houses, green paddocks of wheat and corn, the great slow river itself dotted with boats and barges all seemed in a 
way to belong to her" (Wright 19). Wright inherited this spontaneous love for nature and like her grandmother who admired the stranger birds ranging from brolgas, parrots, butcher- birds and friar-birds, Wright shared similar intense passion in birds watching vividly penned in her collected book of poems called Birds. Meredith Mc. Kinney, Wright's daughter in her introduction to Birds writes: "These poems are not just about the birds: they seek, in their varying voices and rhythms as well as their images, to somehow be that bird, to embody it".

Towards the end of The Generation of Men we come across the landscape of plentitude:

"The whole country was a great cornucopia filled to overflowing...Every where the grass was rich and the water plentiful.... with the promise of wealth" (Wright 212).

Wrights' grandmother after the demise of her husband attempts at an imaginary possession of her past, by cherishing the 'altered landscape' "as a symbol of the rewards which her own race had won, and was still winning...The piece of land, brought in the space of one generation from untouched forest to obedient fruitfulness, should have remained, she felt inarticulately as a glorious possession and memorial" (Wright 228). This process of domesticating space into a place of settlement with the family especially in the colonial context is interesting. Family has always been the so called 'feminine' realm in the paternal colonial scenario of Australia where men are predominantly engaged in explorations and mastering of 'virgin land'. In regard to this I would like to refer to Deborah Chambers' essay Family as Place: Family Photograph Albums and the Domestication of Public and Private Space where she theorizes how family photography is an "'authentic' witness of the colonization of new alien space" (Chamber 35). What is interesting is her observation that women, who are in oblivion in the epoch making history of colonization are predominantly present in "private narratives, in the context of compiling albums as celebratory, memorialized and nostalgic representations of parenthood and childhood" (Chamber 35). The ideology of space where the land is inscribed with fond memories, nostalgia, and personal significance is also found among generation of women among the Wright family where each significant elements of the land is like series of photographs sedimented in their memory or in diaries or writings like Wright's own poems.

The 'open space' therefore becomes gradually a zone of comfort through these mental associations and memories from past. Paul Carter in Road to Botany Bay writes about this sense of association that is extremely essential for the settler since it provides a kind of stability, a bounded place that enables the viewer to locate himself or herself within a protected zone as Wrights' past generations attempted several times be it by fencing in real 
physical term or through memories of associations. The space therefore transforms into a cultural place with the development of roads, railways and enclosures of any kind. This reminds how Wright describes the development of railways first time in the valley that led to grand celebrations since "the railway was a great thing, and new prosperity was hoped from it" (Wright 53).

What is interesting is that Albert made this heart-shaped lawn as a valentine for May and it is bordered by all English trees like pines, chestnuts and roses. The colonial clearing of the Australian landscape was the design of enlightenment logic that, in its pursuit of certainty and order, sought to eradicate spatial and auditory ambiguity from an unfamiliar environment. The coloniser's pursuit of blank space-the fantasy of settler society-flattened a textured and "uncultivated" landscape into the one-dimensional Cartesian line of reason. This attempt to master the unfamiliar and remodel the contours of the land, by separating territories, parceling agricultural blocks, and mapping coastlines, resulted in the imaginary death of a complex ecology. This material imprint of a philosophical position - the Cartesian reverence for the continuous line of thought - actually dematerialised the multi-dimensions of a living environment, collapsing everything into the representational form of the linear line, and systematising both human and environmental history. Static and univocal in its one-dimensionality, this line-as a design on the world - cannot accommodate dynamic ecologies or, in a more abstract sense, wandering and impromptu encounters. It does not lead out to the other and, writes Carter, "enjoys no choreographic relation ... no friction ... no suffering, no incision, no bleeding" (Lie of 8). In the Cartesian imaginary, the coloniser's line sits heavily upon the ground. Here, there is no discourse; it is the line alone that can "speak".

In Australia, techniques of deforesting and tilling initiated by the early settlers, the ancestors Wright depicts, inscribed this anthropocentric vision of human separation from, and control over, the environment onto the land. Agential power, the power of making, was credited to the human world alone, and the land transformed into the stage for a multiplicity of cultural signs (Carter 9). Carter describes this as the theatricalisation of the environment whereby, conceptually compacted and physically cleared in a new cultural vision, the nonhuman world was reduced to signifying a human story, yielding to translation and both physically and psychically affording uninhibited movement for the coloniser through space (Carter 10). It re-imagined the land as clear, "announc[ing] a new field of operational interest" for the colonising body (Carter 10). As Carter explained in The Road to Botany Bay, a name is a self-perpetuating poetic creation. Names construct an environment necessary to sustain their own story. They do not describe what is there, but speak from the outside, naming the material world through "the semblances of things known or near at hand" (Carter 12), that is, prior knowledges and histories. Colonisers found legitimacy in imagining a ground that had no 
capacity to answer back or contest the lines drawn upon it, and their stories became foundational.

The authoring of a non-dynamic relation between the coloniser and the Australian environment in The Generation of Men ensures that bodies-inspace are regulated kinetically as well as poetically. Movement is central to Wright's understanding of place-making, and more broadly to the act of poetic invention. It is crucial to the telling of ancestral stories, to the design of things, and relies upon the recognition of selves as spatially situated in the world: to walk, to speak or to make means to intuit a range of potential encounters and poses. It is to always project our bodies forward in time. Our instant capacity to measure intervals, to judge proximities, to assess the scale of things evidences what Carter calls in his Lie of the Land an "eido-kinetic environmental awareness" (Carter 13). We are "placed" through our negotiations of a spatial field. The achievement of a cleared land, or tabula rasa, therefore relied upon the suppression of this eido-kinetic awareness. The removal of bush, the leveling of ground, and the construction of roads and railways as straight lines of passage correlated to an ideology of progress and individualism that discouraged, or even prohibited, untimely meetings between self and other. Culturally, this meant a diminished capacity for kinetic variations and the resulting remaking of place. As the sole agents on a colonial stage, humans are destined to move as isolated units, propelled by internal dynamics alone. There is no room for an uncertain place on the ground. Consequently, to trip up and lose one's footing is to display an individual evolutionary unfitness, rather than admit to being caught up in the world. What this cultural-mnemonic story, that Wright initiated, promoted was a community that interacted as passing projectiles, unmarked by the moment of encounter. Here, no convergence of interests could ever be discovered: no dimples, folds or slopes remained in the social field where different folk might come together or significantly depart. As the environment suffered from the dematerialised line, so did community in the hard re-membering of passages. As David Harvey has noted in his The Condition of Postmodernity:

If it is true that time is always memorialized not as flow, but as memories of experienced places and spaces, then history must indeed give way to poetry. (Harvey 218)

While for the woman it is a land of admiration, for the lonely man in the course of his story of exploration, the landscape is often eroticized. The masculine gaze traverses the field and the flesh as a site of pleasure or as the desired object to be taken control of and explored. "For the first time he felt the place to be his home....he tried to look at the country with new eyes .... its hills blue with the cold blue of the spring weather, the long lagoon, the flocks of black duck, egrets that waded there, the water hens with their red-beaks and purple blue plumage" (Wright 87). In another section Albert thinks the landscape as "a piece of knowledge that ought not to be wasted, the map in his head....he 
did not like idea of raping and leaving it" (Wright 51). The book attempts to capture this transfiguration of the vast stretch of psychological topography as a figment of white Australian history ranging from fear, disgust, anxiety, and existential crisis to love, peace, and a cathartic search for healing the deserted soul. The landscape becomes then as natural corollaries to human mindscape.

Landscape is in fact a "way of seeing". While the settlers look at the nation's landscape as an object of exploration, adaptation and imposition, the natives find it in their consciousness. Wright, far removed from the imperialists' vision, looks for the metonymic significance in the landscape itself. In her process of cultural determinism she delineates the inherent relationship between the aborigines and the land simultaneously reflecting on the repressed sense of guilt in the past generations: "the whites knew that from the tribesmen's point of view they were trespassing on country where they had no rights" (Wright 16). Wright decodes the western appropriation and wrenching of the landscape, and penetrates deep into its roots to show the inter-relationship between the land and the natives. She transgresses all limits in search of the vast ubiquitous residual landscape to know the aesthetic relation between the aborigines and the land. Describing the struggle and the gradual perishing of the tribes Wright depicts how the landscape seems to be corresponding mysteriously and partaking in the process of death:

"Albert was reminded of the queer swarthy native cherry trees that grew in these hills, always near a certain kind of big gum tree. When the gum tree was felled, it seemed as though some mysterious relationship had been abruptly broken; the native cherry began to droop and wither, and in a few moths would be dead, though its roots were whole and it seemed to bear no wound. It was in that way that the blacks were dying; quietly as though they had chosen death." (Wright 182)

Wright's mode here foregrounds the visuality of narrative in its oscillation between the affective registers of response and the categorizing impulses of taxonomy. In fact the iconic valency of the gum-tree is further intensified if one remembers Wright's lines in the poem "Scribbly -gum" in her anthology The Two Fires:

The gum-tree stands by the spring.

I peeled its splitting bark

And found the written track

Of a life I could not read. (Human Pattern 75)

The attempt to master the unfamiliar and remodel the contours of the land, by marking territories, dividing agricultural blocks, and mapping coastlines, 
resulted in the imaginary death of a complex ecology and an economy of expression: the aboriginal oral narratives and rock-arts. The spiritual dimension of the landscape for Wright is incomplete unless one feels the landscape for what it is and its people. The land withholds the aborigines as an essential element of itself-the corroboree and the 'bora' ring mingled 'with the warm muddy smell of the lagoon water" endows the land with a living essence, it meant for Wright a way to connect the concrete sensory perceptions with spatial contexts, to understand the resilient life that the landscape breathes. Wright attempted this interaction with the landscape through her poetry. Far removed from the features of colonial topography Wright was more concerned to etch the chaotic possibility of the matrix of the vast Australian landscapes. The meaning of a landscape lies in its opacity, in its resistance to the power of interpretation, in its reification of itself as the accessible but unidentifiable. And hence even after several remodeling of the contours of the land, developing railways and dividing agricultural blocks it remains unknown:

"He looked out at the moonlight flooding the clearing round the huts; beyond he could see the faraway glow of the fires over the river. The faint wailing cry possessed the night, mournful as the cry of curlews in the scrub. He wished he knew its meaning." (Wright 198)

Like the French philosopher Gaston Bachelard's idea of the 'desire-path', in his seminal work The Poetics of Space, a term in landscape architecture that is used to describe a path that is not designed but rather is worn casually away by people finding the shortest distance between two points, Wright searches from the ossified remains of time about aborigines and their mysterious trysts with the land without recourse to the western traditions of nomenclature, travel, narration, and cartography.

In the words of Pierce Lewis "our human landscape is our unwitting autobiography, reflecting our tastes, our values, our aspirations, and even our fears in tangible visible form...All our cultural warts and blemishes are there, and our glories too..." (Lewis 12). In The Generation of Men, the landscape appears to be a text where Wright painstakingly unleashes all the plethora of constructed meanings the settlers imposed to search for the organic relationship between the aborigines and the land. Wright makes an honest confession and forays into the secret domain of the heart of her forefathers revealing that "To forgive oneself - that was the hardest task. Until the white men could recognize and forgive that deep and festering consciousness of guilt in themselves...the murder would go on--- open or concealed" (Wright 183).

This essay has been an exploration of the process through which the vital act of imaginative creation, that sutures together a definitive body of history through experience, has been carried out in The Generation of Men , a 
process I will refer to as 'spatial memory'. Spatial memory, in Wright's work, implies more than the recalling of spaces and places of significance to the author. It is, rather, a process by which these spaces come to be 'revisioned', repeatedly re-inscribed with new meaning and value until they become mythologised spaces.

The process of recollecting what is there occurs in Wright's text precisely through the writing of a place. Only when one has that writing place has one got the autobiographical experience. The autobiographical experience is not conjured up by going back, in a tourist way, to look at the verandah, the underpinnings of the house: it emerges in the writing of those places, their transformation into, literally, memory places. For Wright, time is understood spatially, and space temporally. In The Generation of Men Wright was trying to delineate the relationship between time and space under extreme, but by no means extraordinary conditions. She was concerned with what one might call the space-time of the self.

Wright became deaf towards the end of her life but her enthralling relationship with the land remained eternal as evidenced in "Woman to Child" in her anthology Woman to Man where she writes:

I am the earth, I am the root

I am the stem that fed the fruit,

The link that joins you to the night. (Human Pattern 22)

\section{Works Cited}

Bachelard, Gaston. The Poetics of Space. Maria Jolas (Tr.) Boston: Beacon Books. 1969.

Carter, Paul. The Road to Botany Bay : An Essay in Spatial History. London \& Boston : Faber and Faber, 1987.

-------The Lie of the Land. London: Faber and Faber, 1996.

Chambers, Deborah. Family as Place: Family Photograph Albums and the Domestication of Public and Private Space. Picturing Place: Photography and the Geographical Imagination. Joan M. Schwartz \& James R. Ryan (ed.). London: I.B.Tauris Publishers, 2003.

Lewis, Pierce. Axioms for Reading the Landscape: some guides to the American Scene. The Interpretation of Ordinary Landscapes. D.W Meinig (ed). London: Oxford University Press, 1979.

Mitchell, W. J. T. Landscape and Power. Chicago: University of Chicago Press, 1994.

Wright, Judith. The Generation of Men. Melbourne: Oxford University Press, 1956.

-------A Human Pattern: Selected Poems. Manchester: Carcanet Press, 1992.

Devaleena Das is a Lecturer in Gurudas Mahavidyalay, West Bengal, India. Email: devaleena.83@gmail.com 